\title{
Article \\ Admission High-Sensitive Cardiac Troponin T Level Increase Is Independently Associated with Higher Mortality in Critically Ill Patients with COVID-19: A Multicenter Study
}

\author{
Romaric Larcher ${ }^{1,2, *(\mathbb{D} \text {, Noemie Besnard }}{ }^{3}$, Aziz Akouz ${ }^{4}$, Emmanuelle Rabier ${ }^{5}$, Lauranne Teule ${ }^{4}$, \\ Thomas Vandercamere ${ }^{5}$, Samuel Zozor ${ }^{1}$, Matthieu Amalric ${ }^{3}$, Racim Benomar ${ }^{3}$, Vincent Brunot ${ }^{3}$, \\ Philippe Corne $^{3}$, Olivier Barbot ${ }^{4}$, Anne-Marie Dupuy ${ }^{1} \mathbb{D}$, Jean-Paul Cristol ${ }^{1,2,+}$ and Kada Klouche ${ }^{2,3,+}$
}

Citation: Larcher, R.; Besnard, N.; Akouz, A.; Rabier, E.; Teule, L.; Vandercamere, T.; Zozor, S.; Amalric, M.; Benomar, R.; Brunot, V.; et al. Admission High-Sensitive Cardiac Troponin T Level Increase Is Independently Associated with Higher Mortality in Critically Ill Patients with COVID-19: A Multicenter Study. J. Clin. Med. 2021, 10, 1656. https://doi.org/10.3390/ jcm10081656

Academic Editor:

Pierre-Grégoire Guinot

Received: 26 February 2021

Accepted: 10 April 2021

Published: 13 April 2021

Publisher's Note: MDPI stays neutral with regard to jurisdictional claims in published maps and institutional affiliations.

Copyright: (C) 2021 by the authors Licensee MDPI, Basel, Switzerland. This article is an open access article distributed under the terms and conditions of the Creative Commons Attribution (CC BY) license (https:// creativecommons.org/licenses/by/ $4.0 /)$.
1 Biochemistry and Hormonology Department, Lapeyronie Hospital, University Hospital of Montpellier, 34090 Montpellier, France; s-zozor@chu-montpellier.fr (S.Z.); am-dupuy@chu-montpellier.fr (A.-M.D.); jp-cristol@chu-montpellier.fr (J.-P.C.)

2 PhyMedExp, University of Montpellier, INSERM, CNRS, Arnaud de Villeneuve Hospital, University Hospital of Montpellier, 34090 Montpellier, France; k-klouche@chu-montpellier.fr

3 Intensive Care Medicine Department, Lapeyronie Hospital, University Hospital of Montpellier, 34090 Montpellier, France; n-besnard@chu-montpellier.fr (N.B.); amalric.matthieu@gmail.com (M.A.); r-benomar@chu-montpellier.fr (R.B.); v-brunot@chu-montpellier.fr (V.B.); p-corne@chu-montpellier.fr (P.C.)

4 Intensive Care Unit, Hospital of Perpignan, 66000 Perpignan, France; aziz.akouz@ch-perpignan.fr (A.A.); lauranne.teule@ch-perpignan.fr (L.T.); barbot.olivier@ch-perpignan.fr (O.B.)

5 Intensive Care Unit, Hospital of Narbonne, 11100 Narbonne, France; manuerabier@hotmail.fr (E.R.); thomasvandercamere@yahoo.fr (T.V.)

* Correspondence: r-larcher@outlook.fr; Tel.: +(0033)-4-67-33-83-15

+ Contributed equally to this work as last authors.

Abstract: Background: In coronavirus disease 2019 (COVID-19) patients, increases in high-sensitive cardiac troponin $\mathrm{T}$ (hs-cTnT) have been reported to be associated with worse outcomes. In the critically ill, the prognostic value of hs-cTnT, however, remains to be assessed given that most previous studies have involved a case mix of non- and severely ill COVID-19 patients. Methods: We conducted, from March to May 2020, in three French intensive care units (ICUs), a multicenter retrospective cohort study to assess in-hospital mortality predictability of hs-cTnT levels in COVID-19 patients. Results: 111 laboratory-confirmed COVID-19 patients (68\% of male, median age 67 (58-75) years old) were included. At ICU admission, the median Charlson Index, Simplified Acute Physiology Score II, and $\mathrm{PaO}_{2} / \mathrm{FiO}_{2}$ were at 3 (2-5), 37 (27-48), and 140 (98-154), respectively, and the median hs-cTnT serum levels were at $16.0(10.1-31.9) \mathrm{ng} / \mathrm{L}$. Seventy-five patients $(68 \%)$ were mechanically ventilated, $41(37 \%)$ were treated with norepinephrine, and 17 (15\%) underwent renal replacement therapy. In-hospital mortality was $29 \%(32 / 111)$ and was independently associated with lower $\mathrm{PaO}_{2} / \mathrm{FiO}_{2}$ and higher hs-cTnT serum levels. Conclusions: At ICU admission, besides $\mathrm{PaO}_{2} / \mathrm{FiO}_{2}$, hs-cTnT levels may allow early risk stratification and triage in critically ill COVID-19 patients.

Keywords: COVID-19; SARS-CoV-2; high-sensitive cardiac troponin T; myocardial injury; outcomes; ICU

\section{Introduction}

Coronavirus disease 2019 (COVID-19), caused by severe acute respiratory syndrome coronavirus 2 (SARS-CoV-2) infection, has spread worldwide, resulting in a dramatic pandemic [1]. The number of COVID-19 cases is still dramatically increasing all around the world, and health systems confronting the pandemic have to face intensive care unit (ICU) resource scarcity [2]. Early risk stratification and identification of predictive factors of mortality in critically ill patients are therefore an important matter of concern in order to determine suitability for transfer to the ICU and to perform optimal follow-up and management. 
In ICU settings, COVID-19 has initially been mainly associated with acute respiratory distress syndrome (ARDS), but evidence of multiple organ dysfunction, including myocardial injury, has been reported [3-6]. Cardiac disease in patients with COVID-19 has therefore been recognized as a common condition associated with a more severe clinical course and increased mortality $[7,8]$. In the same line, increases in cardiac troponin (cTn), also known as myocardial injury, have been reported to be associated with worse outcomes in patients with COVID-19 [8-15]. However, the prognostic value of cardiac biomarkers in COVID-19 critically ill patients have not yet been clearly defined. Obviously, data in the ICU population remains scarce, since almost all studies have involved a case mix of non-severe and severe patients, or few ICU patients [16-19].

The aim of this multicentric study was to assess the prognostic value of high-sensitive cardiac troponin $\mathrm{T}$ (hs-cTnT) levels at ICU admission in patients with critical SARS-CoV2 infection.

\section{Materials and Methods}

\subsection{Study Design and Settings}

This observational retrospective cohort study was carried out from 9 March 2020 to 3 May 2020 in three French ICUs. Investigators on each site collected prospectively clinical and biological data for all critically ill patients diagnosed with COVID-19. Patients were followed up until hospital discharge or death and three months later by phone call.

\subsection{Participants}

All consecutive patients with a SARS-CoV-2 infection confirmed by RT-PCR who were at least 18 years old and admitted to the ICU during the study period were included. Patients with suspected COVID-19 but not confirmed by SARS-CoV-2 RT-PCR and those who did not have an hs-cTnT measurement within the first $24 \mathrm{~h}$ of ICU admission were excluded.

\subsection{Data Collection}

Demographical and clinical data, including morbidities, were collected. Patients' prior health status was evaluated by the Charlson Comorbidity Index [20]. Chronic heart disease was defined as a medical history of myocardial infarction, coronary ischemia treated by angioplasty and/or stents, cardiac surgery, or chronic heart failure (i.e., exertional or paroxysmal nocturnal dyspnea that has responded to digitalis, diuretics, or afterloadreducing agents). The severity of disease was assessed $24 \mathrm{~h}$ after ICU admission using the Simplified Acute Physiology Score (SAPS) II [21]. At ICU admission, the oxygen arterial partial pressure to the fraction of inspired oxygen $\left(\mathrm{PaO}_{2} / \mathrm{FiO}_{2}\right)$ ratio [22] was recorded. Biological data were also collected at admission, particularly hs-cTnT, $\mathrm{C}$ reactive protein (CRP), and D-dimer. The D-dimer level was determined using D-Dimer HS 500 assay on ACL TOP 700 analyzer (Werfen, Barcelona, Spain). Procalcitonin (PCT) was determined using the BRAHMS PCT assay based on TRACE (Time-Resolved Amplified Cryptate Emission) on the Kryptor Gold ${ }^{\odot}$ instrument (ThermoScientific, BRAHMS AG, Hennigsdorf, Germany). All other biological parameters, such as hs-cTnT, serum creatinine, CRP, and lactate, were performed on a Cobas 8000 instrument using e802 and c702 modules (Roche Diagnostic, Meylan, France).

Within the first five days of ICU admission, a transthoracic echocardiography was performed using a Vivid S70 ultrasound machine (GE Healthcare, Horton, Norway), equipped with a M5S (1.4-4.6MHz) cardiac probe allowing M-mode and two-dimensional measurements. Ventricular systolic function was assessed by measuring the ejection fraction (EF) from the mean of three measurements in different cardiac cycles using the biplane disc summation method and by calculation of fractional shortening, from the reduction of the right ventricular (LV) internal diameter during the cardiac cycle (modified Simpson method). Tricuspid annular plane systolic excursion (TAPSE) measurements were also performed using M-mode. Left ventricular dysfunction was defined as a left ventricular ejection fraction $(\mathrm{LVEF})<50 \%$, whereas right ventricular dysfunction was 
defined with a TAPSE measurement $<15 \mathrm{~mm}$. A cardiac dysfunction was considered to be present in case of left or/and right ventricular dysfunction.

Therapies instituted during ICU stay, including vasoactive drugs, invasive mechanical ventilation, renal replacement therapy, and extracorporeal membrane oxygenation (ECMO), were recorded.

The ICU length of stay and the outcome, including ICU, in-hospital, and 90-day mortalities, were recorded. Predictive factors of in-hospital mortality were then identified.

\subsection{Statistical Analysis}

Data are described as median and interquartile range (IQR) or number and percentage. The population was divided into two groups according to vital status at hospital discharge. Categorical variables were compared using the Chi-square test and continuous variables using the nonparametric Wilcoxon test. Mortality is displayed as Kaplan-Meier plots and compared using log-rank tests. Risk factors associated with in-hospital mortality and need for invasive mechanical ventilation were assessed using univariable and multivariable cox regression. For the multivariable analysis, variables were selected according to their statistical significance in univariable analysis (with a $p$-value $<0.2$ ). Because of skewed distributions, biomarker values were log-transformed before modeling. Proportional hazard assumption was assessed by inspecting the scaled Shoenfeld residuals and regression splines. Hazard ratios (HRs) were given with a $95 \%$ confidence interval. The sensitivity and specificity of the factors associated with in-hospital mortality were assessed and receiver operating characteristic (ROC) curves were plotted. The optimal cut-off values were estimated by maximizing the Youden index. The risk factors associated with the occurrence of cardiac dysfunction were assessed using a logistic regression model. All tests were two-sided and a $p$-value less than 0.05 was considered statistically significant. R software version 4.0.2 (Free Software Foundation, Boston, MA, USA) was used for analyses.

\section{Results}

\subsection{Study Population}

Among the 184 patients admitted to ICUs with suspected COVID-19, 73 were excluded: 14 because of non-confirmed diagnosis and 59 because of missing data (Figure 1). One hundred and eleven patients (75 males, $68 \%$ ) with a median age of 67 (58-75) years were then included in the study. As shown in Table 1, the median Charlson Index was 3 (2-5) and most of the patients $(48 \%)$ had at least two comorbid conditions such as hypertension $(47 \%)$, diabetes $(31 \%)$, chronic heart diseases $(20 \%)$, chronic pulmonary disease $(20 \%)$, or chronic kidney disease (13\%).

At ICU admission, the median SAPS II was 37 (27-48). The severity of patients' illnesses was mainly related to respiratory failure, given that the median $\mathrm{PaO}_{2} / \mathrm{FiO}_{2}$ ratio at admission was 140 (98-154) and severe acute respiratory distress syndrome (ARDS) according to the Berlin definition occurred in almost one third of the patients (31\%). Almost all patients $(83 \%)$ included in the study were admitted to the ICU from the emergency department or after a hospital stay in the ward of $\leq 24 \mathrm{~h}$.

The biological data at admission are summarized in Table 1. A huge elevation of CRP and D-dimer was observed at $153(112-222) \mathrm{mg} / \mathrm{L}$ and $890(572-1950) \mathrm{ng} / \mathrm{mL}$, respectively. Levels of cTnT were increased over the 99th percentile (>14 ng/L) in 61 patients $(55 \%)$ and above $52 \mathrm{ng} / \mathrm{L}$ in 18 patients (16\%). The PCT values were low and mostly under the cutoff value of $0.5 \mathrm{ng} / \mathrm{mL}$ (median PCT at $0.4(0.2-0.9) \mathrm{ng} / \mathrm{mL}$ ). 


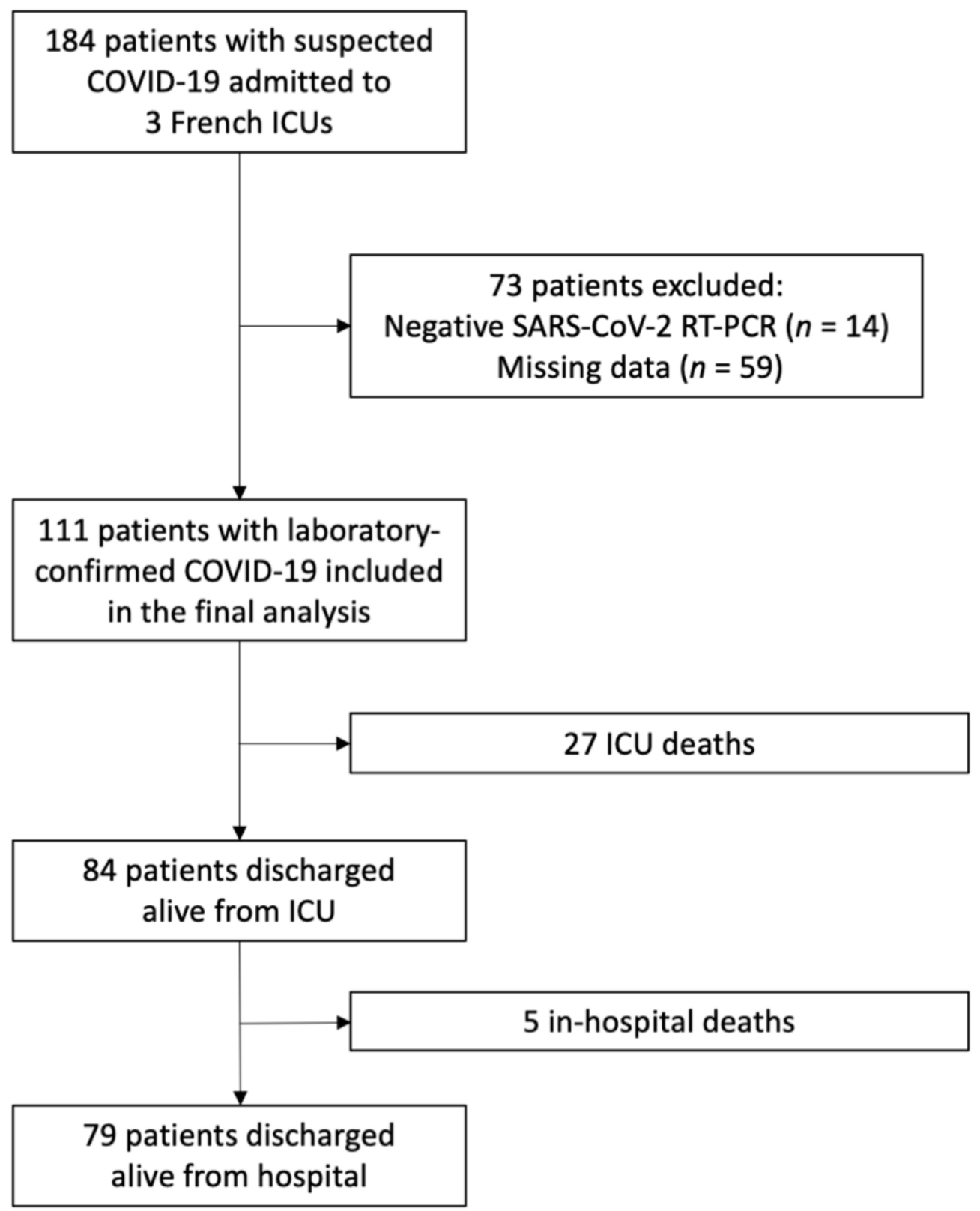

Figure 1. Flow chart of the study population. ICU, intensive care unit; SARS-CoV-2, severe acute respiratory syndrome coronavirus 2 .

\subsection{Outcomes}

During ICU stay, more than two third of patients (75 patients, $68 \%$ ) required invasive mechanical ventilation, and among them, 38 (34\% of the whole population and 51\% of mechanically ventilated patients) needed - in addition-a prone positioning, and three required a veno-venous ECMO (3\%) for refractory hypoxemia. Acute kidney injury at a KDIGO stage $\geq 1$ occurred in 66 patients $(60 \%)$ and $17(15 \%)$ underwent renal replacement therapy. Norepinephrine $(\geq 1 \mu \mathrm{g} / \mathrm{kg} / \mathrm{min})$ was administered in 41 (37\%) patients, mainly in the case of vasoplegic shock, except in five patients who had mixed cardiogenic and vasoplegic shock. Dobutamine was administered in one patient. A bacterial infection (six pneumonia, two bacteremia, and one urosepsis) was documented concomitantly with the SARS-CoV-2 infection in nine patients treated with norepinephrine. 
Table 1. Baseline characteristics of the study population and mortality.

\begin{tabular}{|c|c|c|c|c|}
\hline & Total $(n=111)$ & Non-Survivor $(n=32)$ & Survivor $(n=79)$ & $p$-Value \\
\hline Age (years), median (IQR) & $67(58-75)$ & $75(67-81)$ & $63.0(56-72)$ & $<0.001$ \\
\hline Male, $n(\%)$ & $75(68 \%)$ & $16(50 \%)$ & $59(75 \%)$ & 0.01 \\
\hline $\mathrm{BMI}^{1}\left(\mathrm{~kg} / \mathrm{m}^{2}\right)$, median (IQR) & $28(25-32)$ & $26(23-31)$ & $28(25-32)$ & 0.57 \\
\hline Hypertension, $n(\%)$ & $52(47 \%)$ & $18(56 \%)$ & $34(43 \%)$ & 0.21 \\
\hline Diabetes, $n(\%)$ & $33(31 \%)$ & $12(38 \%)$ & $22(28 \%)$ & 0.32 \\
\hline Chronic heart disease, $n(\%)$ & $22(20 \%)$ & $10(31 \%)$ & $12(15 \%)$ & 0.06 \\
\hline Chronic kidney disease, $n(\%)$ & $14(13 \%)$ & $8(25 \%)$ & $6(8 \%)$ & 0.02 \\
\hline Chronic pulmonary disease, $n(\%)$ & $22(20 \%)$ & $11(34 \%)$ & $11(14 \%)$ & 0.02 \\
\hline Charlson Index, median (IQR) & $3(2-5)$ & $5(4-8)$ & $3(2-4)$ & $<0.001$ \\
\hline SAPS II $^{2}$, median (IQR) & $37(27-48)$ & $43(34-54)$ & $33(25-46)$ & 0.01 \\
\hline $\mathrm{PaO}_{2} / \mathrm{FiO}_{2}$, median (IQR) & $140(98-154)$ & $100(85-139)$ & $160(105-206)$ & 0.003 \\
\hline $\mathrm{PaO}_{2} / \mathrm{FiO}_{2} \leq 100, n(\%)$ & $34(31 \%)$ & $17(53 \%)$ & $17(22 \%)$ & 0.002 \\
\hline Invasive mechanical ventilation, $n(\%)$ & $75(68 \%)$ & $25(78 \%)$ & $50(63 \%)$ & 0.14 \\
\hline Duration (days), median (IQR) & $10(5-19)$ & $9(6-16)$ & $12(5-18)$ & - \\
\hline Prone positioning, $n(\%)$ & $38(34 \%)$ & $14(44 \%)$ & $24(30 \%)$ & 0.02 \\
\hline $\mathrm{ECMO}^{3}, n(\%)$ & $3(3 \%)$ & $1(3 \%)$ & $2(3 \%)$ & 0.86 \\
\hline Duration (days), median (IQR) & $17(14-20)$ & - & - & - \\
\hline $\begin{array}{l}\text { Norepinephrine }(>1 \mu \mathrm{g} / \mathrm{kg} / \mathrm{min}), n \\
(\%)\end{array}$ & $41(37 \%)$ & $17(53 \%)$ & $24(30 \%)$ & 0.03 \\
\hline Duration (days), median (IQR) & $7(4-12)$ & $9(5-15)$ & $5(3-10)$ & - \\
\hline $\mathrm{RRT}^{4}, n(\%)$ & $17(15 \%)$ & $10(31 \%)$ & $7(9 \%)$ & 0.005 \\
\hline Duration (days), median (IQR) & $14(4-31)$ & $10(3-19)$ & $22(10-38)$ & - \\
\hline $\begin{array}{l}\text { Creatininemia }(\mu \mathrm{mol} / \mathrm{L}), \text { median } \\
(\mathrm{IQR})\end{array}$ & $84(62-111)$ & $92(72-168)$ & $82(57-101)$ & 0.01 \\
\hline hs-cTnT ${ }^{5}$ (ng/L), median (IQR) & $16.0(10.2-31.9)$ & $35.0(16.8-106.0)$ & $12.5(7.5-20.0)$ & $<0.001$ \\
\hline $\mathrm{CRP}^{6}(\mathrm{mg} / \mathrm{L})$, median (IQR) & $153(112-222)$ & $134(93-215)$ & $154(115-223)$ & 0.45 \\
\hline $\mathrm{PCT}^{7}$ (ng/mL), median (IQR) & $0.4(0.2-0.9)$ & $0.6(0.3-1.3)$ & $0.3(0.2-0.9)$ & 0.11 \\
\hline Lactatemia (mmol/L), median (IQR) & $1.3(0.9-1.7)$ & $1.3(0.8-1.8)$ & $1.3(1.0-1.6)$ & 0.62 \\
\hline D-dimer (ng/mL), median (IQR) & $890(572-1950)$ & $1340(658-1958)$ & $859(497-1861)$ & 0.09 \\
\hline $\operatorname{LVEF}^{8}(\%)$, median (IQR) & $60(50-60)$ & $55(50-60)$ & $60(50-60)$ & 0.28 \\
\hline $\operatorname{TAPSE}^{9}(\mathrm{~mm})$, median (IQR) & $18(16-22)$ & $18(14-23)$ & $18(17-22)$ & 0.49 \\
\hline ICU $\operatorname{LOS}^{10}$ (days), median (IQR) & $10(6-18)$ & $8(5-17)$ & $10(6-18)$ & - \\
\hline Hospital LOS (days), median (IQR) & $19(11-31)$ & $10(7-22)$ & $21(13-34)$ & - \\
\hline Death, $n(\%)$ & $32(29 \%)$ & - & - & - \\
\hline
\end{tabular}

${ }^{1}$ BMI, body mass index; ${ }^{2}$ SAPS II, Simplified Acute Physiology Score II; ${ }^{3}$ ECMO, extracorporeal membrane oxygenation; ${ }^{4}$ RRT, renal replacement therapy; ${ }^{5}$ hs-cTnT, high-sensitive cardiac troponin T; ${ }^{6} \mathrm{CRP}, \mathrm{C}$ reactive protein; ${ }^{7} \mathrm{PCT}$, procalcitonin; ${ }^{8} \mathrm{LVEF}$, left ventricular ejection fraction (evaluated in a subset of 66 patients); ${ }^{9}$ TAPSE, tricuspid annular plane systolic excursion (evaluated in a subset of 66 patients); ${ }^{10}$ ICU LOS, intensive care unit length of stay.

In 66 patients, echocardiography was performed, and the median LEVF was $60 \%$ (50-60\%). A cardiac dysfunction was diagnosed in 15 (23\%) of these 66 patients (Table S1). Two patients had pulmonary embolism without right ventricular dysfunction, shock, or hs-cTnT elevation.

Thirty-two patients died before hospital discharge, showing a mortality rate of $29 \%$. Median ICU and hospital lengths of stay were five (2-13) and 27 (14-49) days; three months later, all discharged patients from the hospital were still alive (Table 1). The ninety-day survival probability was $72 \%(64-81 \%)$.

\subsection{Factors Associated with In-Hospital Mortality}

By univariable analysis, age, sex, and a high Charlson Index were significantly associated with in-hospital mortality. At admission, higher SAPS II, a lower $\mathrm{PaO}_{2} / \mathrm{FiO}_{2}$ ratio, and increased serum creatinine and hs-cTnT levels were also significantly associated with mortality (Table 1). During ICU stay, the requirement for vasoactive drugs and/or renal replacement therapy significantly worsen the outcome. 
By multivariable analysis, only a low $\mathrm{PaO}_{2} / \mathrm{FiO}_{2}$ ratio and an elevated hs-cTnT serum level among the variables studied were independently associated with in-hospital mortality (Table 2).

Table 2. Factors associated with in-hospital mortality in critically ill COVID-19 patients.

\begin{tabular}{|c|c|c|c|c|}
\hline & $\begin{array}{l}\text { Univariable Analysis } \\
\text { Hazard Ratio (IC 95\%) }\end{array}$ & $p$-Value & $\begin{array}{l}\text { Multivariable Analysis } \\
\text { Hazard Ratio (IC 95\%) }\end{array}$ & $p$-Value \\
\hline Age & $1.1(1.1-1.2)$ & 0.01 & $1.06(0.99-1.14)$ & 0.11 \\
\hline Male sex & $0.4(0.2-0.81)$ & $<0.001$ & $0.50(0.21-1.05)$ & 0.64 \\
\hline $\mathrm{BMI}^{1}$ & $0.99(0.93-1.1)$ & 0.68 & & \\
\hline Smokers & $0.5(0.068-3.6)$ & 0.49 & & \\
\hline Charlson Index & $1.3(1.2-1.4)$ & $<0.001$ & $4.46(0.26-75.55)$ & 0.30 \\
\hline SAPS II ${ }^{2}$ & $10(1.7-58)$ & 0.01 & $1.06(0.08-13.36)$ & 0.96 \\
\hline $\mathrm{PaO}_{2} / \mathrm{FiO}_{2} \leq 100$ & $3.4(1.7-6.8)$ & $<0.001$ & $4.65(1.81-11.97)$ & 0.001 \\
\hline $\begin{array}{l}\text { Invasive mechanical } \\
\text { ventilation }\end{array}$ & $1.8(0.76-4.1)$ & 0.19 & $2.88(0.76-10.97)$ & 0.12 \\
\hline $\begin{array}{l}\text { Norepinephrine }(>1 \\
\mu \mathrm{g} / \mathrm{kg} / \mathrm{min})\end{array}$ & $2.1(1-4.1)$ & 0.04 & $1.08(0.30-2.84)$ & 0.90 \\
\hline $\begin{array}{l}\text { Renal replacement } \\
\text { therapy }\end{array}$ & $2.9(1.4-6.2)$ & 0.005 & $1.58(0.58-4.31)$ & 0.37 \\
\hline Creatininemia $(\log 10)$ & $8.5(2.3-32)$ & 0.002 & $1.45(0.20-10.73)$ & 0.71 \\
\hline Hs-cTnT ${ }^{3}(\log 10)$ & $4.3(2.5-7.2)$ & $<0.001$ & $4.96(1.92-12.86)$ & $<0.001$ \\
\hline $\mathrm{CRP}^{4}(\log 10)$ & $0.83(0.37-1.9)$ & 0.65 & & \\
\hline $\mathrm{PCT}^{5}(\log 10)$ & $1.7(1-2.9)$ & 0.05 & $1.60(0.60-4.25)$ & 0.3 \\
\hline Lactatemia $(\log 10)$ & $1.8(0.21-16)$ & 0.58 & & \\
\hline D-dimer $(\log 10)$ & $2.4(0.81-6.9)$ & 0.12 & $1.21(0.17-3.95)$ & 0.8 \\
\hline
\end{tabular}

${ }^{1}$ BMI, body mass index; ${ }^{2}$ SAPS II, Simplified Acute Physiology Score II; ${ }^{3}$ hs-cTnT, high-sensitive cardiac troponin T; ${ }^{4} \mathrm{CRP}, \mathrm{C}$ reactive protein; ${ }^{5} \mathrm{PCT}$, procalcitonin.

Of note, the analysis of the 66 patients in which echocardiography was performed failed to demonstrate any association between hs-cTnT serum levels and cardiac function $(p=0.12)$ (Table S1).

\subsection{ROC Curves of the Main Prognostic Factors of Mortality at ICU Admission}

At ICU admission, age, hs-cTnT, and the $\mathrm{PaO}_{2} / \mathrm{FiO}_{2}$ ratio area under the curves (AUCs) for predicting in-hospital mortality were 0.794 (95\% CI, 0.705-0.883), 0.792 (95\% CI, 0.702-0.882), and 0.696 (95\% CI, 0.589-0.802), respectively. The D-dimer and CRP levels showed an ROC-AUC of 0.609, (95\% CI, 0.485-0.734) and 0.539 (95\% CI, 0.410-0.669), respectively. The ROC curves are displayed in Figure 2.

Hs-cTnT has a sensitivity and a specificity at $69 \%$ and $79 \%$, respectively, to predict in-hospital mortality using a cutoff value at $22 \mathrm{ng} / \mathrm{L}$ (Table 3). Age and the $\mathrm{PaO}_{2} / \mathrm{FiO}_{2}$ ratio had a higher specificity ( $81 \%$ and $82 \%$, respectively) but lower sensitivity $(63 \%$ and $50 \%$, respectively) with a cutoff value at 74 years old and 100, respectively. D-dimer, at a cutoff value of $500 \mathrm{ng} / \mathrm{L}$, showed the highest sensitivity (96\%) but the lowest specificity (26\%), and D-dimer $\geq 500 \mathrm{ng} / \mathrm{L}$ also had the highest negative predictive value (NPV) at $94 \%$, whereas hs-cTnT $\geq 22 \mathrm{ng} / \mathrm{L}$, age $\geq 74$ years old, and $\mathrm{PaO}_{2} / \mathrm{FiO}_{2}$ ratio $\leq 100$ had an NPV of $86 \%, 84 \%$, and $80 \%$, respectively. All factors had low positive predictive values (PPVs). 


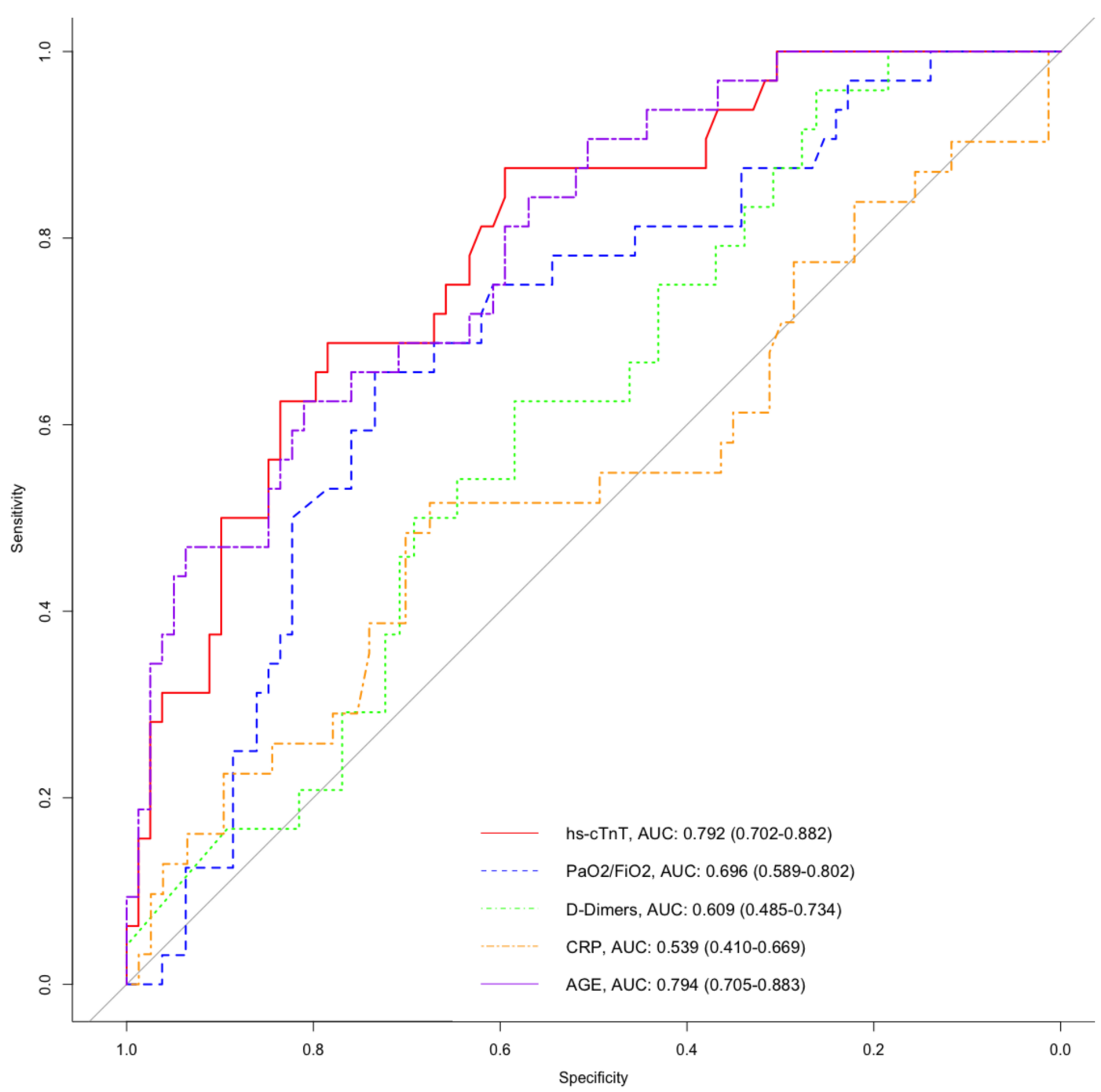

Figure 2. Receiver operating characteristic (ROC) curves of age (purple semi-dashed line), initial $\mathrm{PaO}_{2} / \mathrm{FiO}_{2}$ ratio (blue dashed line), initial high-sensitive cardiac troponin T (hs-cTnT, red line), initial D-Dimer (green dotted line), and initial $\mathrm{C}$ reactive protein (CRP, orange dashed and dotted line) for predicting in-hospital mortality in critically ill patients with COVID-19.

Table 3. Sensibility, specificity, positive, and negative predictive values for mortality prediction in critically ill patients with COVID-19.

\begin{tabular}{|c|c|c|c|c|}
\hline & Sensibility (\%) & Specificity (\%) & PPV $^{1}(\%)$ & $\mathrm{NPV}^{2}(\%)$ \\
\hline age $\geq 74$ years old & 63 & 81 & 57 & 84 \\
\hline hs-cTnT ${ }^{3} \geq 22 \mathrm{ng} / \mathrm{L}$ & 69 & 79 & 56 & 86 \\
\hline $\mathrm{PaO}_{2} / \mathrm{FiO}_{2} \leq 115$ & 66 & 73 & 50 & 84 \\
\hline $\mathrm{PaO}_{2} / \mathrm{FiO}_{2} \leq 100$ & 50 & 82 & 53 & 80 \\
\hline D-dimer $\geq 500 \mathrm{ng} / \mathrm{L}$ & 96 & 26 & 34 & 94 \\
\hline $\mathrm{CRP}^{4} \geq 135 \mathrm{mg} / \mathrm{L}$ & 52 & 68 & 39 & 78 \\
\hline
\end{tabular}

${ }^{1} \mathrm{PPV}$, positive predictive value; ${ }^{2} \mathrm{NPV}$, negative predictive value; ${ }^{3} \mathrm{hs}$-cTnT, high-sensitive cardiac troponin $\mathrm{T}$, ${ }^{4} \mathrm{CRP}, \mathrm{C}$ reactive protein. The optimal cutoff value of each variable estimated by maximizing the Youden index was selected, except for $\mathrm{PaO}_{2} / \mathrm{FiO}_{2} \leq 100$, which is the threshold of the Berlin definition for severe acute respiratory distress syndrome.

Ninety-day survival was significantly altered according to the level of hs-cTnT and the $\mathrm{PaO}_{2} / \mathrm{FiO}_{2}$ ratio. The corresponding Kaplan-Meier curves are displayed in Figure 3. 
A

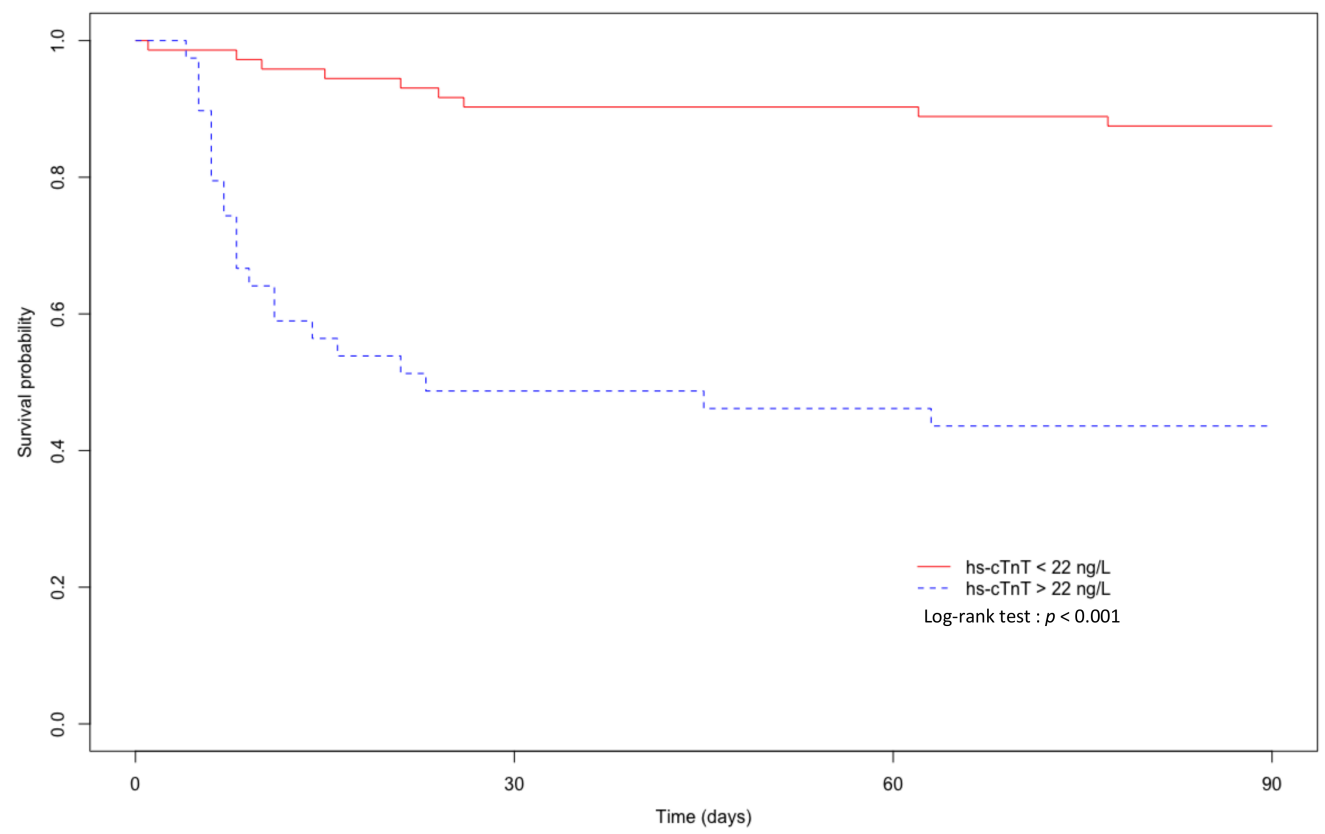

No at risk

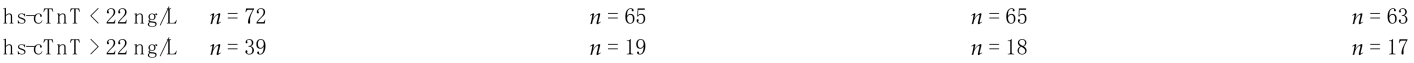

B

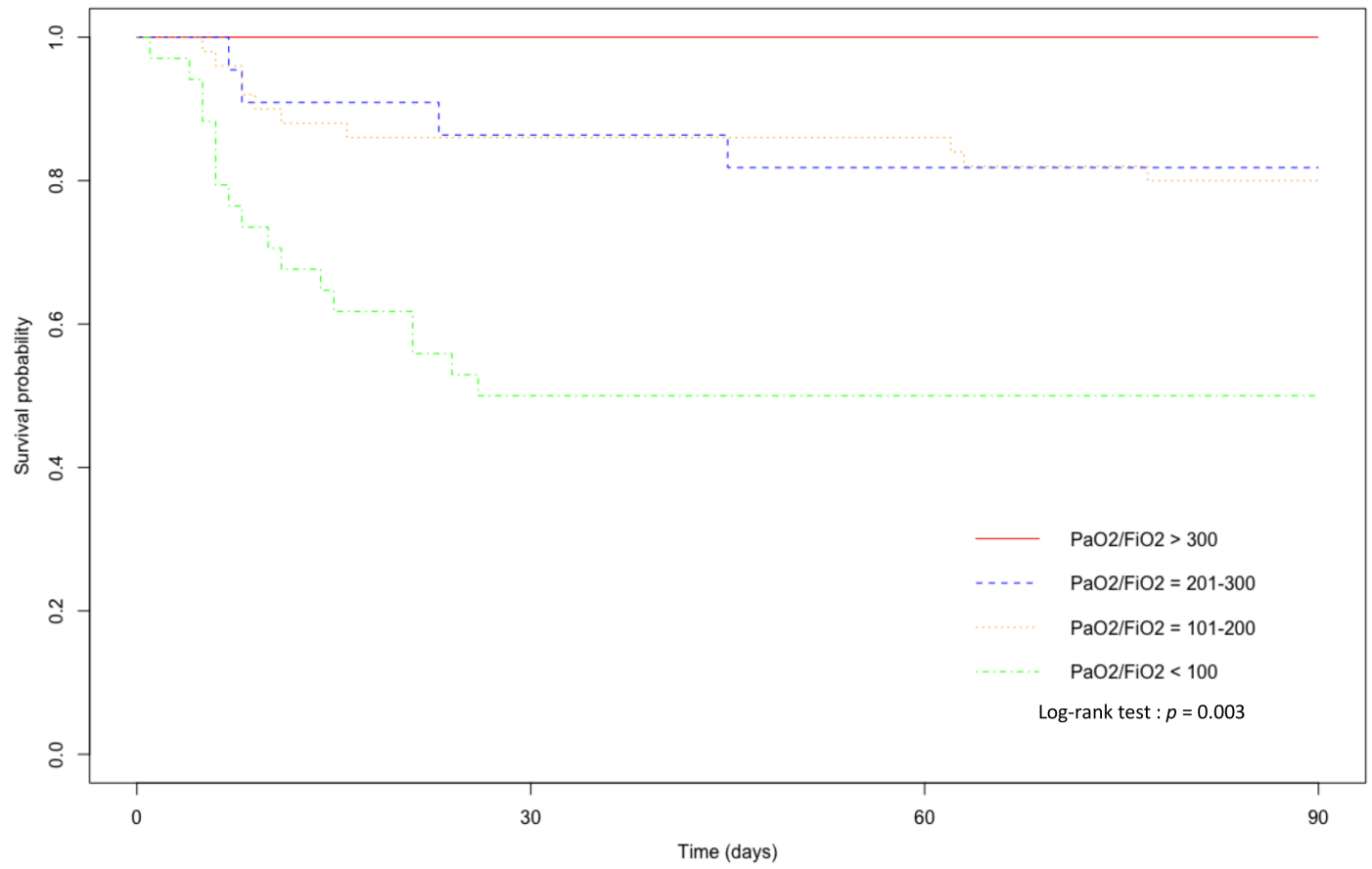

$\mathrm{N}$ o atrisk

$\begin{array}{ll}\mathrm{PaO}_{2} / \mathrm{FiO}_{2}>300 & n=5 \\ \mathrm{PaO}_{2} / \mathrm{FiO}_{2}=201-300 & n=22\end{array}$

$\mathrm{PaO}_{2} / \mathrm{FiO}_{2}=101-200 \quad n=50$

$\mathrm{PaO}_{2} / \mathrm{FiO}_{2} \leqslant 100 \quad n=34$

$n=5$
$n=19$
$n=43$
$n=17$

$n=5$

$n=18$

$n=43$

$n=17$

$n=5$

$n=18$

$n=40$

$n=17$

Figure 3. Kaplan-Meier curve of 90-day survival after ICU admission of critically ill patients with COVID-19: (A) hs-cTnT $<22 \mathrm{ng} / \mathrm{L}$ versus hs-cTnT $>22 \mathrm{ng} / \mathrm{L}$; (B) no acute respiratory distress syndrome (ARDS) $\left(\mathrm{PaO}_{2} / \mathrm{FiO}_{2}>300\right)$ versus mild $\left(\mathrm{PaO}_{2} / \mathrm{FiO}_{2}=201-300\right)$, moderate $\left(\mathrm{PaO}_{2} / \mathrm{FiO}_{2}=101-200\right)$, and severe ARDS $\left(\mathrm{PaO}_{2} / \mathrm{FiO}_{2} \leq 100\right)$. 


\subsection{Factors Associated with Invasive Mechanical Ventilation Needs}

By univariable analysis, age, high Charlson Index and SAPS II, a low $\mathrm{PaO}_{2} / \mathrm{FiO}_{2}$ ratio, need for vasoactive drugs, and increased serum hs-cTnT levels were significantly associated with invasive mechanical ventilation (Table S2).

By multivariable analysis, only higher SAPS II was independently associated with invasive mechanical ventilation (Table S2). None of studied biological variables were independently associated with the need for invasive mechanical ventilation.

\section{Discussion}

In this multicentric study, including 111 critically ill laboratory-confirmed COVID-19 patients, we observed an in-hospital mortality rate of $29 \%$. We found that a low $\mathrm{PaO}_{2} / \mathrm{FiO}_{2}$ ratio and elevated hs-cTnT serum levels at ICU admission were independently associated with in-hospital mortality. All variables had a fair negative but low positive value to predict in-hospital mortality.

Previous studies have already reported that a lower $\mathrm{PaO}_{2} / \mathrm{FiO}_{2}$ ratio is associated with mortality in critical COVID-19 patients $[1,12,23,24]$. A lower $\mathrm{PaO}_{2} / \mathrm{FiO}_{2}$ ratio is also recognized as the major determinant predicting morbidity and mortality in patients with non-COVID-19 ARDS [22,25,26]. In addition, we showed in this study that an increase in hs-cTnT is associated with in-hospital mortality in critically ill COVID-19 patients. There is evidence of an association between cTnI levels and mortality in mild-severe COVID-19 patients $[9,16,19,27]$. Moreover, recent meta-analyses have concluded that increased $\mathrm{cTnI}$ levels are significantly associated with the most severe forms of COVID-19 [14,28]. Our observations confirmed these previous reports and are in line with the results recently reported by Demir et al. [29]. However, conflicting results have been reported by Metkus et al. [30], highlighting that the association between cTn elevation and in-hospital mortality of mechanically ventilated COVID-19 patients was weak after adjustment for cofounders, namely, age, sex, and multi-system organ dysfunction. Though they take into account normal values accordingly, the use of both $\mathrm{cTnT}$ and $\mathrm{cTnI}$ measurements may have introduced some bias in their results [30]. Nonetheless, in our study, hs-cTnT levels, as well as $\mathrm{PaO}_{2} / \mathrm{FiO}_{2}$, were independently associated with mortality, given that other organ dysfunctions, age, and gender were included in the multivariable analysis.

In critically ill patients with SARS-CoV-2 infection, several mechanisms could be involved in myocardial injury and the subsequent elevation of hs-cTn levels [31]. Acute myocardial infarction (types 1 and 2) may complicate COVID-19, as reported in acute bacterial or viral infections [32]. In our cohort, though hs-cTnT levels were frequently over the 99th percentile ( $>14 \mathrm{ng} / \mathrm{L}$ ), they rarely crossed $52 \mathrm{ng} / \mathrm{L}$, the cut-off value for myocardial infarction diagnosis [33]. In addition, electro/echocardiographic and hs-cTnT kinetics along ICU stay ruled out myocardial necrosis. COVID-19-associated myocarditis may also induce an increase in troponin [8,31,34-36]. The clinical features of acute myocarditis are heterogeneous, from new-onset heart failure to arrhythmic events, or infarct-like symptoms with usually preserved LVEF [37]. In our patients, the occurrence of acute myocarditis with preserved systolic function could explain the increase in hscTnT without echocardiographic abnormalities. Actually, there are limited reports on SARS-CoV-2-associated myocarditis, and a few autopsy series have shown virus in the myocardium [34,38]. Nonetheless, sepsis, cardiac adrenergic hyperstimulation, and pulmonary embolism could enhance troponin liberation [30,31,35]. Moreover, comorbid conditions such as coronary artery disease, chronic ischemic cardiomyopathy, or hypertension, which are common in COVID-19 patients $[7,12,13]$, may also contribute to troponin elevation. Regardless, COVID-19 led to inflammation, endothelial dysfunction, hypercoagulation state, hypoxia, and hemodynamic instability that may induce myocardial injury and, consequently, troponin elevation $[8,10,13,16,34,38,39]$.

Our results are in line with those previously reported in septic critically ill patients regarding both $\mathrm{cTnT}$ and $\mathrm{cTnI}$ levels [40-43], suggesting that cTnT levels may add to risk stratification and in a better manner than inflammatory or thrombotic markers in COVID- 
19 patients [9,16-19]. Though a recent meta-analysis have highlighted the prognostic value of increased CRP and D-dimer plasma levels in non-severe and severe COVID-19 [44], the value of such markers in ICU settings is flawed, given that they are frequently increased, as we observed in our patients $[16,45]$. Our results should prompt intensivists to pay attention to hs-cTnT levels, in addition to the $\mathrm{PaO}_{2} / \mathrm{FiO}_{2}$ ratio, among critically ill patients admitted with SARS-CoV-2 infection for triage and risk stratification. A higher admission severity score may also help to predict the need for invasive mechanical ventilation.

We must acknowledge some limitations to this study. First, it was limited by its retrospective design, inducing bias in data collection and result interpretation. Some hscTnT missing values forced us to exclude 59 patients, but this work is the largest multicenter analysis on the prognostic value of cTn in ICU settings. Second, hs-cTnT levels were not systematically monitored during ICU stay. Obviously, hs-cTnT kinetics would be very informative in both diagnosis and prognosis in this population. Last, echocardiography was performed in a small subset of included patients. Moreover, endomyocardial biopsy and cardiac magnetic resonance imaging might have been useful for diagnosis of acute myocarditis, particularly for those with preserved systolic function.

\section{Conclusions}

In conclusion, elevated troponin plasmatic concentrations are commonly observed in critically ill COVID-19 patients. We showed that, at admission, myocardial injury and a low $\mathrm{PaO}_{2} / \mathrm{FiO}_{2}$ ratio were strongly associated with in-hospital mortality. These variables may help for an early and best risk stratification in such patients. Further studies are, however, mandatory to confirm our results.

Supplementary Materials: The following are available online at https:/ /www.mdpi.com/article/10 $.3390 / \mathrm{jcm} 10081656 / \mathrm{s} 1$, Table S1: Echocardiographic evaluation in 66 patients with critical coronavirus disease 2019 (COVID-19); Table S2: Risk factors associated with invasive mechanical ventilation needs in critically ill COVID-19 patients.

Author Contributions: Conceptualization, R.L., J.-P.C., and K.K.; methodology, R.L., J.-P.C., and K.K.; software, R.L.; validation, A.-M.D., J.-P.C., and K.K.; formal analysis, R.L., A.-M.D., J.-P.C., and K.K.; investigation, R.L., N.B., A.A., E.R., L.T., T.V., and S.Z.; resources, R.L.; data curation, R.L.; writing—original draft preparation, R.L.; writing—review and editing, A.-M.D., J.-P.C., and K.K.; visualization, M.A., R.B., V.B., P.C. and O.B.; supervision, J.-P.C. and K.K.; project administration, R.L. and K.K. All authors have read and agreed to the published version of the manuscript.

Funding: This research received no external funding.

Institutional Review Board Statement: This study was conducted according to the guidelines of the Declaration of Helsinki, and approved by the Institutional Review Board of Montpellier University Hospital (IRB-MTP_2020_11_202000644, accessed on 16 November 2020). This study was also registered at ClinicalTrials.gov (NCT04641988), accessed on 23 November 2020).

Informed Consent Statement: The Institutional Review Board of Montpellier University Hospital waived the need for signed consent to participate, according to the French laws.

Data Availability Statement: The authors consent to share the collected data with others. Data will be provided to qualified investigators free of charge, after careful examination of required documents (summary of the research plan, request form, and IRB approval) by the study board of investigators. Data will be available immediately after the main publication and indefinitely.

Acknowledgments: This work is dedicated to the loving memory of Nils Kuster, talented pharmacist and biochemist.

Conflicts of Interest: The authors declare no conflict of interest. 


\section{References}

1. Guan, W.J.; Ni, Z.Y.; Hu, Y.; Liang, W.H.; Ou, C.Q.; He, J.X.; Liu, L.; Shan, H.; Lei, C.L.; Hui, D.S.C.; et al. Clinical Characteristics of Coronavirus Disease 2019 in China. N. Engl. J. Med. 2020, 382, 1708-1720. [CrossRef] [PubMed]

2. Alhazzani, W.; Møller, M.H.; Arabi, Y.M.; Loeb, M.; Gong, M.N.; Oczkowski, S.; Levy, M.M.; Derde, L.; Dzierba, A.; Du, B.; et al. Surviving Sepsis Campaign: Guidelines on the Management of Critically Ill Adults with Coronavirus Disease 2019 (COVID-19). Intensive Care Med. 2020, 104, 854-887. [CrossRef] [PubMed]

3. Zheng, Y.-Y.; Ma, Y.-T.; Zhang, J.-Y.; Xie, X. COVID-19 and the cardiovascular system. Nat. Rev. Cardiol. 2020, 17, 259-260. [CrossRef] [PubMed]

4. Madjid, M.; Safavi-Naeini, P.; Solomon, S.D.; Vardeny, O. Potential Effects of Coronaviruses on the Cardiovascular System: A Review. JAMA Cardiol. 2020, 5, 831. [CrossRef] [PubMed]

5. $\quad$ Fried, J.A.; Ramasubbu, K.; Bhatt, R.; Topkara, V.K.; Clerkin, K.J.; Horn, E.; Rabbani, L.; Brodie, D.; Jain, S.S.; Kirtane, A.J.; et al. The Variety of Cardiovascular Presentations of COVID-19. Circulation 2020, 141, 1930-1936. [CrossRef]

6. Li, L.; Hill, J.; Spratt, J.C.; Jin, Z. Myocardial injury in severe COVID-19: Identification and management. Resuscitation 2021, 160, 16-17. [CrossRef]

7. Inciardi, R.M.; Adamo, M.; Lupi, L.; Cani, D.S.; Di Pasquale, M.; Tomasoni, D.; Italia, L.; Zaccone, G.; Tedino, C.; Fabbricatore, D.; et al. Characteristics and outcomes of patients hospitalized for COVID-19 and cardiac disease in Northern Italy. Eur. Heart J. 2020, 41, 1821-1829. [CrossRef]

8. Shi, S.; Qin, M.; Cai, Y.; Liu, T.; Shen, B.; Yang, F.; Cao, S.; Liu, X.; Xiang, Y.; Zhao, Q.; et al. Characteristics and clinical significance of myocardial injury in patients with severe coronavirus disease 2019. Eur. Heart J. 2020, 41, 2070-2079. [CrossRef]

9. Huang, C.; Wang, Y.; Li, X.; Ren, L.; Zhao, J.; Hu, Y.; Zhang, L.; Fan, G.; Xu, J.; Gu, X.; et al. Clinical features of patients infected with 2019 novel coronavirus in Wuhan, China. Lancet 2020, 395, 497-506. [CrossRef]

10. Zhou, F.; Yu, T.; Du, R.; Fan, G.; Liu, Y.; Liu, Z.; Xiang, J.; Wang, Y.; Song, B.; Gu, X.; et al. Clinical course and risk factors for mortality of adult inpatients with COVID-19 in Wuhan, China: A retrospective cohort study. Lancet 2020, 395, 1054-1062. [CrossRef]

11. Chen, R.; Liang, W.; Jiang, M.; Guan, W.; Zhan, C.; Wang, T.; Tang, C.; Sang, L.; Liu, J.; Ni, Z.; et al. Risk Factors of Fatal Outcome in Hospitalized Subjects With Coronavirus Disease 2019 From a Nationwide Analysis in China. Chest 2020, 158, 97-105. [CrossRef]

12. Wang, Y.; Lu, X.; Li, Y.; Chen, H.; Chen, T.; Su, N.; Huang, F.; Zhou, J.; Zhang, B.; Yan, F.; et al. Clinical Course and Outcomes of 344 Intensive Care Patients with COVID-19. Am. J. Respir. Crit. Care Med. 2020, 201, 1430-1434. [CrossRef]

13. Guo, T.; Fan, Y.; Chen, M.; Wu, X.; Zhang, L.; He, T.; Wang, H.; Wan, J.; Wang, X.; Lu, Z. Cardiovascular Implications of Fatal Outcomes of Patients With Coronavirus Disease 2019 (COVID-19). JAMA Cardiol. 2020, 5, 811-818. [CrossRef] [PubMed]

14. Lippi, G.; Lavie, C.J.; Sanchis-Gomar, F. Cardiac troponin I in patients with coronavirus disease 2019 (COVID-19): Evidence from a meta-analysis. Prog. Cardiovasc. Dis. 2020, 63, 390-391. [CrossRef]

15. Du, R.-H.; Liang, L.-R.; Yang, C.-Q.; Wang, W.; Cao, T.-Z.; Li, M.; Guo, G.-Y.; Du, J.; Zheng, C.-L.; Zhu, Q.; et al. Predictors of mortality for patients with COVID-19 pneumonia caused by SARS-CoV-2: A prospective cohort study. Eur. Respir. J. 2020, 55, 2000524. [CrossRef] [PubMed]

16. Wang, D.; Hu, B.; Hu, C.; Zhu, F.; Liu, X.; Zhang, J.; Wang, B.; Xiang, H.; Cheng, Z.; Xiong, Y.; et al. Clinical Characteristics of 138 Hospitalized Patients With 2019 Novel Coronavirus-Infected Pneumonia in Wuhan, China. JAMA 2020, 323, 1061-1069. [CrossRef] [PubMed]

17. Arentz, M.; Yim, E.; Klaff, L.; Lokhandwala, S.; Riedo, F.X.; Chong, M.; Lee, M. Characteristics and Outcomes of 21 Critically Ill Patients With COVID-19 in Washington State. JAMA 2020, 323, 1612. [CrossRef] [PubMed]

18. Bhatraju, P.K.; Ghassemieh, B.J.; Nichols, M.; Kim, R.; Jerome, K.R.; Nalla, A.K.; Greninger, A.L.; Pipavath, S.; Wurfel, M.M.; Evans, L.; et al. Covid-19 in Critically Ill Patients in the Seattle Region-Case Series. N. Engl. J. Med. 2020, 382, $2012-2022$. [CrossRef] [PubMed]

19. Ruan, Q.; Yang, K.; Wang, W.; Jiang, L.; Song, J. Clinical predictors of mortality due to COVID-19 based on an analysis of data of 150 patients from Wuhan, China. Intensiv. Care Med. 2020, 46, 846-848. [CrossRef] [PubMed]

20. Charlson, M.; Szatrowski, T.P.; Peterson, J.; Gold, J. Validation of a combined comorbidity index. J. Clin. Epidemiol. 1994, 47, 1245-1251. [CrossRef]

21. Le Gall, J.-R.; Lemeshow, S.; Saulnier, F. A New Simplified Acute Physiology Score (SAPS II) Based on a European/North American Multicenter Study. JAMA 1993, 270, 2957-2963. [CrossRef]

22. Force, A.D.T.; Ranieri, V.M.; Rubenfeld, G.D.; Thompson, B.T.; Ferguson, N.D.; Caldwell, E.; Fan, E.; Camporota, L.; Slutsky, A.S. Acute Respiratory Distress Syndrome: The Berlin Definition. JAMA 2012, 307, 2526-2533. [CrossRef]

23. Karagiannidis, C.; Mostert, C.; Hentschker, C.; Voshaar, T.; Malzahn, J.; Schillinger, G.; Klauber, J.; Janssens, U.; Marx, G.; Weber-Carstens, S.; et al. Case characteristics, resource use, and outcomes of 10021 patients with COVID-19 admitted to 920 German hospitals: An observational study. Lancet Respir. Med. 2020, 8, 853-862. [CrossRef]

24. Grasselli, G.; Zangrillo, A.; Zanella, A.; Antonelli, M.; Cabrini, L.; Castelli, A.; Cereda, D.; Coluccello, A.; Foti, G.; Fumagalli, R.; et al. Baseline Characteristics and Outcomes of 1591 Patients Infected with SARS-CoV-2 Admitted to ICUs of the Lombardy Region, Italy. JAMA 2020, 323, 1574-1581. [CrossRef]

25. Herridge, M.S.; Chu, L.M.; Matte, A.; Tomlinson, G.; Chan, L.; Thomas, C.; Friedrich, J.O.; Mehta, S.; Lamontagne, F.; Levasseur, M.; et al. The RECOVER Program: Disability Risk Groups and 1-Year Outcome after 7 or More Days of Mechanical Ventilation. Am. J. Respir. Crit. Care Med. 2016, 194, 831-844. [CrossRef] 
26. Villar, J.; Ambrós, A.; Soler, J.A.; Martínez, D.; Ferrando, C.; Solano, R.; Mosteiro, F.; Blanco, J.; Martín-Rodríguez, C.; Fernández, M.D.M.; et al. Age, PaO2/FIO2, and Plateau Pressure Score: A Proposal for a Simple Outcome Score in Patients with the Acute Respiratory Distress Syndrome. Crit. Care Med. 2016, 44, 1361-1369. [CrossRef] [PubMed]

27. Gunduz, R.; Yildiz, B.S.; Ozdemir, I.H.; Cetin, N.; Ozen, M.B.; Bakir, E.O.; Ozgur, S.; Bayturan, O. CHA2DS2-VASc score and modified CHA2DS2-VASc score can predict mortality and intensive care unit hospitalization in COVID-19 patients. J. Thromb. Thrombolysis 2021. [CrossRef] [PubMed]

28. Danwang, C.; Endomba, F.T.; Nkeck, J.R.; Wouna, D.L.A.; Robert, A.; Noubiap, J.J. A meta-analysis of potential biomarkers associated with severity of coronavirus disease 2019 (COVID-19). Biomark. Res. 2020, 8, 1-13. [CrossRef] [PubMed]

29. Demir, O.M.; Ryan, M.; Cirillo, C.; Desai, N.; Pericao, A.; Sinclair, H.; Stylianidis, V.; Victor, K.; Alaour, B.; Jones, A.; et al. Impact and Determinants of High-Sensitivity Cardiac Troponin-T Concentration in Patients With COVID-19 Admitted to Critical Care. Am. J. Cardiol. 2021. [CrossRef] [PubMed]

30. Metkus, T.S.; Sokoll, L.J.; Barth, A.S.; Czarny, M.J.; Hays, A.G.; Lowenstein, C.J.; Michos, E.D.; Nolley, E.P.; Post, W.S.; Resar, J.R.; et al. Myocardial Injury in Severe COVID-19 Compared with Non-COVID-19 Acute Respiratory Distress Syndrome. Circulation 2021, 143, 553-565. [CrossRef]

31. Sandoval, Y.; Januzzi, J.L.; Jaffe, A.S. Cardiac Troponin for Assessment of Myocardial Injury in COVID-19. J. Am. Coll. Cardiol. 2020, 76, 1244-1258. [CrossRef]

32. Musher, D.M.; Abers, M.S.; Corrales-Medina, V.F. Acute Infection and Myocardial Infarction. N. Engl. J. Med. 2019, 380, 171-176. [CrossRef]

33. Collet, J.-P.; Thiele, H.; Barbato, E.; Barthélémy, O.; Bauersachs, J.; Bhatt, D.L.; Dendale, P.; Dorobantu, M.; Edvardsen, T.; Folliguet, T.; et al. 2020 ESC Guidelines for the management of acute coronary syndromes in patients presenting without persistent ST-segment elevation. Eur. Heart J. 2020, 79. [CrossRef]

34. Doyen, D.; Moceri, P.; Ducreux, D.; Dellamonica, J. Myocarditis in a patient with COVID-19: A cause of raised troponin and ECG changes. Lancet 2020, 395, 1516. [CrossRef]

35. Imazio, M.; Klingel, K.; Kindermann, I.; Brucato, A.; De Rosa, F.G.; Adler, Y.; De Ferrari, G.M. COVID-19 pandemic and troponin: Indirect myocardial injury, myocardial inflammation or myocarditis? Heart 2020, 106, 1127-1131. [CrossRef]

36. Lala, A.; Johnson, K.W.; Januzzi, J.L.; Russak, A.J.; Paranjpe, I.; Richter, F.; Zhao, S.; Somani, S.; Van Vleck, T.; Vaid, A.; et al. Prevalence and Impact of Myocardial Injury in Patients Hospitalized With COVID-19 Infection. J. Am. Coll. Cardiol. 2020, 76, 533-546. [CrossRef]

37. Caforio, A.L.P.; Pankuweit, S.; Arbustini, E.; Basso, C.; Gimeno-Blanes, J.; Felix, S.B.; Fu, M.; Heliö, T.; Heymans, S.; Jahns, R.; et al. Current state of knowledge on aetiology, diagnosis, management, and therapy of myocarditis: A position statement of the European Society of Cardiology Working Group on Myocardial and Pericardial Diseases. Eur. Heart J. 2013, 34, 2636-2648. [CrossRef]

38. Jonigk, D.; Märkl, B.; Helms, J. COVID-19: What the clinician should know about post-mortem findings. Intensiv. Care Med. 2021, 47, 86-89. [CrossRef] [PubMed]

39. Klok, F.A.; Kruip, M.J.H.A.; van der Meer, N.J.M.; Arbous, M.S.; Gommers, D.A.M.P.J.; Kant, K.M.; Kaptein, F.H.J.; van Paassen, J.; Stals, M.A.M.; Huisman, M.V.; et al. Incidence of thrombotic complications in critically ill ICU patients with COVID-19. Thromb. Res. 2020, 191, 145-147. [CrossRef]

40. Klouche, K.; Pommet, S.; Amigues, L.; Bargnoux, A.S.; Dupuy, A.M.; Machado, S.; Serveaux-Delous, M.; Morena, M.; Jonquet, O.; Cristol, J.P. Plasma Brain Natriuretic Peptide and Troponin Levels in Severe Sepsis and Septic Shock: Relationships with Systolic Myocardial Dysfunction and Intensive Care Unit Mortality. J. Intensiv. Care Med. 2012, 29, 229-237. [CrossRef] [PubMed]

41. Kim, J.-S.; Kim, M.; Kim, Y.-J.; Ryoo, S.M.; Sohn, C.H.; Ahn, S.; Kim, W.Y. Troponin Testing for Assessing Sepsis-Induced Myocardial Dysfunction in Patients with Septic Shock. J. Clin. Med. 2019, 8, 239. [CrossRef] [PubMed]

42. Gayat, E.; Cariou, A.; Deye, N.; Vieillard-Baron, A.; Jaber, S.; Damoisel, C.; Lu, Q.; Monnet, X.; Rennuit, I.; Azoulay, E.; et al. Determinants of long-term outcome in ICU survivors: Results from the FROG-ICU study. Crit. Care 2018, 22, 1-10. [CrossRef]

43. Landesberg, G.; Jaffe, A.S.; Gilon, D.; Levin, P.D.; Goodman, S.; Abu-Baih, A.; Beeri, R.; Weissman, C.; Sprung, C.L.; Landesberg, A. Troponin Elevation in Severe Sepsis and Septic Shock: The Role of Left Ventricular Diastolic Dysfunction and Right Ventricular Dilatation. Crit. Care Med. 2014, 42, 790-800. [CrossRef] [PubMed]

44. Moutchia, J.; Pokharel, P.; Kerri, A.; McGaw, K.; Uchai, S.; Nji, M.; Goodman, M. Clinical laboratory parameters associated with severe or critical novel coronavirus disease 2019 (COVID-19): A systematic review and meta-analysis. PLoS ONE 2020, 15, e0239802. [CrossRef] [PubMed]

45. Auld, S.C.; Caridi-Scheible, M.; Blum, J.M.; Robichaux, C.; Kraft, C.; Jacob, J.T.; Jabaley, C.S.; Carpenter, D.; Kaplow, R.; HernandezRomieu, A.C.; et al. ICU and Ventilator Mortality Among Critically Ill Adults with Coronavirus Disease 2019. Crit. Care Med. 2020. [CrossRef] 